DOI: https://doi.org/10.22364/RL.4.13

\title{
Determinants un situants latviešu valodā un to novietojums teikumā
}

\section{Dative-marked adjuncts and temporal and local adjuncts in Latvian: word order in the sentence}

\author{
Baiba Saulite \\ Latvijas Universitātes \\ Matemātikas un informātikas institūts \\ Raina bulv. 29, Rīga, LV-1050 \\ E-pasts: baiba.valkovska@lumii.lv
}

Latviešu sintakses teorija nav iedomājama bez Intas Freimanes devuma, viņas skaidrās, sistēmiskās pieejas teikuma sintaktiskajai struktūrai. Savos darbos viņa postulējusi un analizējusi arī determinatīvus ārpusshēmas komponentus. Lai gan šis sintaktiskā sakara veids škiet problemātisks gan noteikšanas kritēriju, gan terminolog̣ijas dēḷ, šāda pieeja teikuma struktūrai saglabāta arī mūsdienu latviešu sintaksē. Determinatīvi ārpusshēmas komponenti ir svarīgi teikuma semantiskajā, sintaktiskajā un komunikatīvajā struktūrā, tie var piesaistīt teikumu konkrētai runas situācijai un bieži ir ziņojuma sākumpunkts. Šajā rakstā analizēta determinatīvu ārpusshēmas paplašinātāju izpratnes attīstība latviešu valodniecībā, kā arī raksturota determinatīvu ārpusshēmas komponentu nozīme teikuma komunikatīvajā struktūrā.

Atslēgvārdi: determinants; situants; vārdu secība; tēma; rēma.

\section{Determinatīvā sakara izpratne}

Mūsdienu latviešu valodniecībā tiek uzskatīts, ka uz determinatīvā sakara pamata teikumā iesaistās ārēji teikuma paplašinātāji, kuri neizriet no izteicēja vai galvenā locekla valences un kuru forma un semantika ar izteicēju vai galveno locekli nekādā veidā nav saistīta (piem., Lokmane 2013, 757). Šie ārējie teikuma paplašinātāji ir (Skujiņa 2007, 361):

1) determinanti, kas nosauc izjutēju vai to, kuram kas pieder, un ko izsaka ar datīvu,

2) situanti jeb apstākḷi, kas attiecas uz visu teikumu kopumā un nav pakārtoti nevienam vārdam teikumā.

Minētā uzskata pamatā ir Intas Freimanes attīstītā determinatīvu ārpusshēmas komponentu izpratne. I. Freimane (1985, 79), balstoties uz Natālijas Švedovas (Natalija Shvedova) atzinumiem, noškir determinantu semantiskos tipus 
(determinanti ar sinkrētisku subjekta un objekta nozīmi jeb determinanti un determinanti ar adverbiālu nozīmi jeb situanti), tomēr vinas darbos dominē vispārīgākais determinanta jēdziens un determinatīvā sakara paplašinātāji vairāk aprakstìti kopumā, dēvējot tos visus par determinantiem.

Kritiski vērtēto determinanta jēdzienu krievu valodniecībā ieteikusi N. Švedova $(2005,204)$, kura kā l̦oti svarīgas visiem determinantiem raksturīgas pazīmes nosauc pozīciju teikuma sākumā vai nepastarpināti pirms gramatiskā centra un spēju iesaistîties dažādās teikuma struktūrās (piem., gan verbālos, gan adverbiālos teikumos).

N. Švedova sākotnēji ar datīvu izteikto izjutēju vai īpašnieku piedāvājusi saukt par determinējošu objektu, bet vēlāk jau dēvē par determinantu, kas, kā minēts iepriekš, pārņemts arī latviešu valodas sintaksē (sk. Freimane 1984) un saglabāts arī „Latviešu valodas gramatikā” (sk. Lokmane 2013, 758; Lokmane, Valkovska 2013, 799). Jāatzīst, ka termins „determinants” nav īpaši veiksmīgs, jo valodniecībā ar tādas pašas saknes vārdu determiner, determinative 'determinētājs' tiek saprasta gramatiska vienība, kas norāda uz lietvārda vai lietvārda vārdkopas referenci (Matthews 2007, 101), piem., arī Brigita Ceplīte (1971, 203) norāda, ka determinatīva locekḷa funkcija (parasti tādā lieto pronomenus šis, tas, ša $\bar{a} s, t \bar{a} d s)$ ir izteikt anaforisko noteiktību.

Vārdformai, kas izteikta ar netiešo locījumu - datīvu -, parasti atrodas teikuma sākumā (t. i., ir nemarķēta tēma) un semantiski varētu tikt uzskatīta par teikuma priekšmetu, latviešu valodā uzman̄̄bu pievērsis arī Aksels Holvūts (Axel Holvoet 2012, 116; 2015), viņš šādu teikuma locekli sauc arī par kvazisubjektu. Diemžèl līdz šim nav izdevies atrast piemērotāko apzīmējumu ar datīvu izteiktajam ārpusshēmas teikuma loceklim, tāpēc šajā rakstā saglabāts termins „determinants”.

Ārpusshēmas paplašinātāja datīvā ar izjutēja vai ìpašnieka nozīmi (sk. arī Lokmane 2013, 758) jeb determinanta forma (netiešais locījums), semantika un apkaime, kā arī teikuma gramatiskā centra izpratne dažādās apraksta tradīcijās sagādā daudz grūtību. Datīva problemātika sintaksē ir îpaši aktuāla, jo tā nesaraujami saistīta ar tādiem jautājumiem kā teikuma gramatiskais un semantiskais minimums, teikumlocekḷu tipi un to noteikšanas kritēriji (Lokmane 2002, 158).

Analizējot objekta un subjekta sinkrētismu, Arturs Ozols un Jūlijs Kārkliņš piedāvājuši trīslocekḷu gramatisko centru. A. Ozols (1967, 163; 1993, 362) gramatiskā centra komponentu nominatīvā, kam ar verbu izteiktā pazīme piemīt pilnīgi vai vispārīgi, sauc par tiešo teikumpriekšmetu, savukārt komponentu datīvā, kam ar verbu izteiktā pazīme piemīt îpašā aspektā (piem., dậēji), ieteicis saukt par netiešo teikumpriekšmetu vai papildinātājteikumpriekšmetu. A. Ozola pieeju netiešā teikumpriekšmeta, netiešā papildinātāja un papildinātājteikumpriekšmeta norobežošanā analizējusi arī I. Freimane (2013, 28). J. Kārkliņš $(1968,273)$, lai arī piekrìt trīslocekḷu gramatiskā centra pieejai, 
atz̄ist, ka varētu būt tādas formālas sintaktiskas attieksmes, kas realizējas nevis vārdu savienojumā, bet teikumā.

I. Freimane $(1965,58)$, aprakstot vienpersonas verbus, kas biedrojas ar nominatīvu un datīvu, pievērš uzmanību datīva divējādai dabai un norāda: ja verbus, kas apzīmē personīgu attieksmi pret objektīvo realitāti, teikumā lieto bez nominatīva, nešauboties var runāt par datīvu kā netiešo teikuma priekšmetu (piem., viņam dzīve neveicoties), tomēr skaidrība zūd, ja pie verba teikumā ir tiešais teikuma priekšmets nominatīvā (piem., Saimniecēm valodas neveicās). Vēlāk I. Freimane $(1984,56)$ ieteikusi izjutēja un piederības datīvu uzlūkot par determinantu - brīvu teikuma paplašinātāju, kas nav vārdkopu attieksmēs ar izteicēju un samērā brīvi iesaistās teikumā. Lai arī verbālā teikumā determinants līdzinās vārdkopas atkarīgajam komponentam, tas pirmām kārtām ir saistīts ar teikuma gramatisko centru (Freimane 1984, 57).

Tālāk rakstā analizēts determinanta un situanta novietojums teikumos ar dažādām teikuma struktūras shēmām, atsevišķi aplūkoti teikumi, kuri sākas ar determinatīvā sakara paplašinātājiem, t.i., ir tēma, un tādi teikumi, kuros šie ārpusshēmas paplašinātāji ietilpst rēmā.

\section{Determinatīvs ārpusshēmas paplašinātājs - tēma}

Ârpusshēmas paplašinātāji ir nozīmīgi teikuma aktuālajā dalījumā, jo tie latviešu valodā parasti ir nemarķēta tēma (Valkovska 2016, 84).

Determinatīvs ārpusshēmas paplašinātājs kā vienkārša teikuma tēma latviešu valodā ir sastopams l̦oti plaši un daudzveidīgi. Tā kā tas ir teikuma sakaru, nevis vārda sakaru nosacīts paplašinātājs, tā tipiskā vieta ir teikuma sākums un tas piesaistās dažādām teikuma struktūras shēmām.

Situantam tā tipiskajā novietojumā - teikuma sākumā - piemīt kāda netipiska tēmas paz̄̄me: tas reti izsaka zināmo, kontekstā iepriekš minēto informāciju. Biežāk tas sniedz pamatinformāciju par apstākḷiem, kādos realizējas izteikums, tā ieklạujot teikumu noteiktā konsituācijā un nododot rēmas funkciju visam pārējam izteikumam.

Determinants tēmas funkciju bieži uzņemas kā semantiskais subjekts, tas tiek uzskatīts arī par īpašu kreisās valences locekli (sk. Lokmane 2002). Darbības izjutēja determinants - nomens vai nomināla vārdkopa datīvā - bieži parādās teikumos, kuru struktūras shēmu veido darbības vārds būt patstāvīgā - pārsvarā piederības vai eksistences - nozīmē, piem.:

(1) Vingai ${ }^{1}$ esot aknu plācenī̌si sunim.

(2) Man taču ir mazs bērns.

(3) Man ir dzīvoklis Rīgā un no senčiem mantota zeme laukos.

1 Šeit un turpmāk izcelts analizētais teikuma loceklis — viens vai kopā ar tā paplašinātājiem. 
Savukārt adverbiālas nozīmes paplašinātājs parādās teikumos, kuros izteicējs ir būt atrašanās nozīmēe, piem.:

(4) Uz trīs virtuves palodzēm ir deviņi puķu podi.

(5) Arī šodien ap lielo koka galdu bija visi.

Gan determinants (6), gan situants (7) tēmas funkcijā bieži parādās verbālos vienkopas teikumos, piem.:

(6) Irmgardei salst.

(7) Aiz loga visu laiku sniga.

Šādās konstrukcijās determinants (6) vai situants (7) ir gan strukturāli, gan semantiski nozīmīgs - tas piesaista konkrēto teikuma struktūras shēmu noteiktai saziņas situācijai un dod iespēju dalīt teikumu tēmā un rēmā.

Divkopu teikumos ar vienvalentu verbu centrā determinanta $(8,9)$ vai situanta $(10,11)$ piesaistīšana tēmas funkcijā ḷauj teikuma priekšmetam kopā ar izteicēju veikt rēmas funkciju:

(8) Ėdājiem uz pieres izspiedās sviedru lāses.

(9) Mūžsenajiem mirstamās kaites nemetas.

(10) Viñas sejā nozibsnīja tramīgs pārsteigums.

(11) Ledainā vējāa šūpojās dzeltenas spuldzes.

Gan determinanti (12), gan, it īpaši, situanti (13-15) tēmas funkcijā plaši tiek lietoti arī teikumos ar vairākvalentu verbu centrā, piem.:

(12) Miai vārdi slìdēja gar ausìm.

(13) Tagad vini tajā redzēja viens otra acis.

(14) Palagu izšuvumos viņas atainoja pārdzī̃oto.

(15) Visu vakaru Tristāns Izoldei neḷāva kāpt uz klāja.

Determinanti (16) un situanti (17) kā teikuma sākumpunkts nereti izmantoti arī nominālos teikumos, piem.:

(16) Tev vienkāršsi katrs kopā pavadītais mirklis ir svētlaime.

(17) Š $\mathbf{a} d \bar{a} s$ dienās Anetes vēsums šķita divtik absurds.

Tāpat adverbiālos teikumos determinants $(18,19)$ vai situants $(20)$ var būt tēma:

(18) Vecākiem bija patīkami to dzirdēt.

(19) Normālam cilvēkam bija bail palikt trijatā ar Fridrihu un vina čellu.

(20) Savā dzīvoklī man būtu vieglāk.

Situantu iesaistǐšana teikumos ar vienvalentu verbu centrā bieži ietekmē arī teikuma priekšmeta un izteicēja novietojumu - izteicējs ir pirms teikuma 
priekšmeta, piem., ar lokālas $(21,22)$ vai temporālas $(23,24)$ nozīmes situantiem:

(21) No komunikāciju tirdzniecības centra apakšas vēdīja baisma tumsa un mikls siltums.

(22) No tumsas iznira divas gaismas acis, tām nopakal̦ traucās liels furgons.

(23) Ziemā nevar būt pèrkons.

(24) Pēc gada uzsniga jauns un tīrs rīts.

Ja teikums, kur centrā ir vienvalents verbs, sākas ar situantu, teikuma gramatiskajā centrā ir iespējama arī vārdu secība: vispirms teikuma priekšmets, tad - izteicējs. Reizēm šādā pozīcijā teikuma priekšmets ir vairāk uzsvērts, piem., izteikumos, kur realizēts tikai gramatiskais centrs un ārpusshēmas komponents - determinants (25) vai situants (26):

(25) Tur skola esot bijusi.

(26) Man bērns būs.

Biežāk gan šādā secībā teikuma priekšmets ir konsituatīvi saistīts, jau zināms, vai arī verbam piesaistīti citi adverbiālas nozīmes paplašinātāji, un ir svarīgi, ka pirms verba ir teikuma priekšmets, savukārt aiz verba - adverbiālas nozīmes paplašinātāì:

(27) Aizvien biežāk Severīns paklupa uz lìdzenas vietas.

(28) Pa nošmurgātām un sarūsējušām durvīm viņi izkḷuva nama pagrabā.

(29) Kādu nedēlu viņš ieradās darbā piecpadsmit minūtes pirms darba laika sākuma un nosēdèja kantorì lìdz vēlam vakaram.

Arī tad, ja teikuma centrā ir divvalents verbs, ir iespējama secība teikuma priekšmets-izteicējs, aiz izteicēja atstājot vietu papildinātājam, piem.:

(30) Ziemās viṇi sildīja viens otru zaru būdā, k̦êra cilpās zaķus un vārīja kopā ar kaltètajām sēnēm.

Būtiska uz determinatīva sakara pamata piesaistītu teikuma locekḷı pazīme ir novietojums teikumā - tie visbiežāk atrodas teikuma sākumā (Lokmane 2002, 158), tajos ietvertā informācija parasti attiecas uz visu teikumu. Tomēr šo teikuma locekḷ̂u noteikšanā l̦oti svarīga ir arī verba semantika - vai attiecīgais komponents ir verba valences loceklis vai teikuma ārpusshēmas paplašinātājs (t. i., piesaistās uz determinatīva sakara pamata).

Determinatīva sakara paplašinātāja spēja piesaistīties dažādām teikuma struktūras shēmām nostiprina pārliecību, ka tas nav vārda sakaru noteikts paplašinātājs, turklāt tā tipiskā vieta - teikuma sākums - un spēja attiekties uz 
teikuma gramatisko centru vai visu pārējo teikumu l̦auj determinatīva sakara paplašinātāiju uzlūkot par tipisku nemarkiētu tēmu latviešu valodā.

\section{Determinatīvs ārpusshēmas paplašinātājs - rēma vai rēmas sastāvdaḷa}

Determinatīvs ārpusshēmas paplašinātājs var būt novietots nevis teikuma sākumā, bet kādā citā pozīcijā, tāpēc ir būtiski noskaidrot, vai mainās to teikumu komunikatīvā struktūra, kuros determinants vai situants nav novietots teikuma sākumā.

Lai arī atsevišķos gadījumos vārdu secība var noteikt sintaktisko sakaru ciešumu un teikumlocekḷa semantiku, piem., teikumiem Tev tas ir un Tas ir tev ir pilnīgi atšksirīgas nozīmes (Lokmane 2002, 158), parasti determinanta funkcija saglabājas arī netipiskā novietojumā, tikai mainās teikuma aktuālais dalījums. Piem., determinants tieši starp teikuma priekšmetu un izteicēju:

(31) .. tavas baltākās domas man pieder.

(32) .. dzims mums bèrni sudraba karotēm mutē.

Tāpat determinants var būt novietots starp teikuma priekšmetu un kādu adverbiālas nozīmes paplašinātāju:

(33) Ceptas renğges man vienmēr garšojušas.

(34) prieks tam sirdī plauka.

Determinants var atrasties arī pašās teikuma beigās, piem.:

(35) Kibeles gadās visiem.

(36) Patiesībā spirtotie visvairāk garšo tieši moldāviem.

(37) .. mans laiks pieder tikai man.

Ja determinants nav novietots teikuma sākumā, parasti teikumam var pievienoties noteiktas papildnozīmes, piem., emocionāli ekspresīva (daiḷliteratūras stila iezīmes 31. un 32. teikumā), teikuma priekšmeta uzsvērums, izvirzot to teikuma sākumā $(33,34)$, determinanta izcēlums, novietojot to teikuma beigās (35-37).

Adverbiālas nozīmes paplašinātāja - situanta vai apstākḷa - funkcija un novietojums ir diezgan sarežğîts jautājums. Adverbiālas nozīmes teikuma locekḷu novietojums tiek uzskatīts par svarīgu faktoru (par to sk. Freimane 1984, 57), kas nosaka to sintaktisko funkciju - atkarībā no vietas teikumā un verba valences tiem var būt gan brīvā paplašinātāja - situanta - funkcija, gan arī verba atkarīgā locekḷa - apstākḷa - funkcija. Teikuma sākumā izvirzītie situanti var nosaukt iepriekš zināmu teikumā paustā notikuma situatīvo raksturojumu un tādējādi iegūst īpašu lomu aktuālajā dalījumā - tēmas lomu, bet pārējā daḷa ir rēma (Freimane 1984, 64). 
Tātad situanta noteikšanā nevar skatīties tikai uz novietojumu, resp., teikuma sākuma pozīciju. Ir jān̨em vērā arī verba valences īpatnības, piem., verbiem atrasties, stāvēt u. tml., kuriem lokālas nozīmes paplašinātājs ir obligāts, tas savu vārda sakaru nosacīto teikumlocekḷa funkciju saglabā arī teikuma sākumā, piem.:

(38) Ielas galā stāvēja bieza, balta migla.

(39) Puskilometra attālumā no „Skalderiem” atrodas sešas dzīvojamās mājas.

(40) Kafejnīcā ienāca trīs vecākas kundzītes.

Kā redzams, arī šajās konstrukcijās, līdzīgi kā determinanta un situanta iesaistīšanās gadījumā, ir tipiski, ka, adverbiālas nozīmes vārda sakaru nosacītam paplašinātājam izvirzoties teikuma sākumā, mainās teikuma priekšmeta un izteicēja secība.

Arī situanta kā teikuma brīvā paplašinātāja funkcija saglabājas netipiskā novietojumā - teikuma beigās:

(41) Runa taču bija par mīlestību šajā krājumāa.

(42) Mašinnite izrādījās nozagta pirms diviem mēnešiem kādā Latgales mežniecībā.

(43) Pirmie signāli atskanēja drīz.

Situanti starp teikuma priekšmetu un izteicēju vērojami šādos teikumos:

(44) .. mès Latvijā visu laiku tikai raudam [.. ]

(45) .. visas sievas pēc täda pazinojuma skrien uz „Skapi”.

I. Freimane $(2014,53)$ atzīst, ka situantu teorijā sintaksē galvenā loma ir semantikai. Piem., reālā pakārtojumā ir svarīga kā pārvaldītāja verba, tā arī tam piesaistìtā nominālā komponenta semantika un vārdkopu izveides iespējas - situanti paliek ārpus vārdkopām. Dažādas locìjumu - arī prepozicionālu locījumu - formas situantu funkcijā it kā zaudē savu formālo lokāmību, un tad sāk prevalēt leksiskā semantika. Lai precīzāk varētu nošķirt situantus no vārda sakaru nosacìtiem paplašinātāijiem un sīkāk varētu analizēt aktuālā dalījuma izmaiņas teikumos ar mainītu adverbiālas nozīmes paplašinātāja vietu, ir nepieciešami plašāki datos balstīi pētījumi par tipiskajiem adverbiālas nozīmes paplašinātājiem.

\section{Secinājumi}

Par determinanta traktējumu sintaksē ir dažādi viedokḷi, tāpat joprojām trūkst kritēriju situanta un vārda sakaru noteikta adverbiālas nozīmes paplašinātāja nošķiršanā: kā liecina rakstā aplūkotais materiāls, paplašinātāja novietojums bez sīkākas verba valences analīzes nav pietiekams kritērijs. Aktuāls ir 
arī jautājums, vai teikuma informācijas struktūras analīzē vispār ir lietderīgi nošķirt situantus no vārda sakaru nosacītiem adverbiālas (vietas vai laika) nozīmes paplašinātājiem.

Svarīgas ir turpmākas diskusijas par determinatīvā sakara veida nepieciešamību latviešu sintaksē, jo, skaidrojot determinanta jēdzienu starptautiski, nākas saskarties ar terminolog̣iskām un interpretācijas grūtībām. Tomēr latviešu valodas teikuma analīzē šāda sintaktiskā sakara nošķiršana šķiet pavisam dabiska, un varbūt tieši tādēl Intas Freimanes piedāvāto pieeju teikuma sintaktisko sakaru analīzē līdz šim neviens nav kardināli mainījis.

Determinatīva ārpusshēmas paplašinātāja tipiskā vieta - teikuma sākums un spēja attiekties uz teikuma gramatisko centru vai visu pārējo teikumu lauj determinatīva sakara paplašinātāju uzlūkot par tipisku nemarķētu tēmu, kas latviešu valodā ir sastopama ļoti plaši un daudzveidīgi. Determinanti un situanti bieži piesaista konkrēto teikuma struktūras shēmu noteiktai saziņas situācijai, dod iespēju dalīt teikumu tēmā un rēmā, turklāt šo paplašinātāju iesaistǐšanās teikumā nereti ietekmē arī teikuma priekšmeta un izteicēja novietojumu, savukārt, ja ārpusshēmas paplašinātājs novietots rēmā, parasti teikumam pievienojas noteiktas papildnozīmes.

\section{Avots}

Lìdzsvarots mūsdienu latviešu valodas tekstu korpuss, 2013. Pieejams: www.korpuss.lv.

\section{Literatūra}

1. Ceplīte, Brigita. 1971. Kontekstuālā noteiktība. Vārda semantika. Ceplīis, Laimdots (red.). Rīga: Zinātne, 147-215.

2. Freimane, Inta. 1965. Vienpersonas darbības vārdi, kas mūsdienu latviešu literārajā valodā biedrojas ar nominatīvu un datīvu. LPSR Zinātņu Akadèmijas Vēstis. 1 (210), 51-60.

3. Freimane, Inta. 1984. Determinantu (situantu) problēma. LPSR Zinātņu Akadēmijas Vēstis. 7, 55-66.

4. Freimane, Inta. 1985. Vienkāršs teikums un tā paplašināšana. Rīga: Latvijas Valsts universitāte.

5. Freimane, Inta. 2013. Arturs Ozols latviešu valodas sintaksē. Res latvienses. II. Arturs Ozols (1912-1964). In honorem. Latvijas Universitātes Humanitāro zinātn̨u fakultātes Latvistikas un baltistikas nodaḷas raksti. Kalnača, Andra, Lāms, Ojārs (sast. un red.) Rìga: LU Akadēmiskais apgāds, 17-34.

6. Freimane, Inta. 2014. Valoda semantiski funkcionālā aspektā. Valoda: nozīme un forma. 5. Opozīi ijas sintaksē un semantikā. Kalnača, Andra, Lokmane, Ilze (red.). Rīga: LU Akadēmiskais apgāds, 33-61.

7. Holvūts, Aksels. 2012. Vispārīgās sintakses pamati. Rīga: Latviešu valodas ag̊entūra. 
8. Holvoet, Axel. 2015. Non-canonical subjects in Latvian: An obliqueness approach. Contemporary Approaches to Baltic Linguistics. Arkadiev, Petr; Holvoet, Axel; Wiemer, Björn (eds). Berlin, New York: Mouton De Gryuter, 299-324.

9. Kārkliņš, Jūlijs. 1968. Datīva semantisko un strukturālo funkciju problemātika vienkāršā teikumā. Latviešu leksikas attīstība. Zinātniskie raksti. Rīga: Zinātne, 267-297.

10. Lokmane, Ilze. 2002. Datīvs latviešu valodas sintaktiskajā sistēmā. Linguistica Lettica. 10. Rīga: LU Latviešu valodas institūts, 151-161.

11. Lokmane, Ilze. 2013. Vienkārša teikuma formālā (strukturālā) organizācija. Latviešu valodas gramatika. Nītiņa, Daina, Grigorjevs, Juris (red.). Rīga: LU Latviešu valodas institūts, 710-766.

12. Lokmane, Ilze, Valkovska Baiba. 2013. Vienkārša teikuma komunikatīvā struktūra. Latviešu valodas gramatika. Nītiņa, Daina, Grigorjevs, Juris (red.). Rīga: LU Latviešu valodas institūts, 774-800.

13. Matthews, Peter H. 2007. Concise Dictionary of Linguistics. Oxford: Oxford University Press.

14. Shvedova, Natalija. 2005. Russkij jazyk: Izbrannye raboty. Moskva: Jazyki slavjanskoj kul'tury.

15. Ozols, Arturs. 1967. Vārds datīvā kā teikuma loceklis. Raksti valodniecībā. Rīga: Zinātne, 147-206.

16. Ozols, Arturs. 1993. Latviešu tautasdziesmu valoda. 2., labots izdevums. Rīga: Zvaigzne.

17. Skujiņa, Valentīna (red.). 2007. Valodniecības pamatterminu skaidrojošā vārdnīca. Rīga: LU Latviešu valodas institūts.

18. Valkovska, Baiba. 2016. Vārdu secības komunikatīvais aspekts mūsdienu latviešu valodā. Promocijas darbs. Rīga: Latvijas Universitāte.

\section{Summary}

The article deals with dative marked adjuncts (also so called datival quasi-subject) and temporal and locative adjuncts (adverbial modifying entire sentence) focusing on word order in the sentence. This so called determinative relation in contemporary Latvian syntax has been introduced by Inta Freimane.

Dative marked adjuncts and temporal and locative adjuncts are free modifiers, modifying entire clause, they can be involved in sentences with different structural schemes and traditionally are placed at the beginning of the sentence. Consequently, these adjuncts usually correspond to unmarked theme in the information structure of a sentence. It has also been discussed the information structure of the sentences having dative marked adjuncts and temporal and locative adjunct in non-initial position. 